\title{
Description the Attitude of Pre-Diabetes Prevention and its Complications in Bangsal District of Kediri
}

\author{
Erva Elli Kristanti ${ }^{1}$, Vitaria Wahyu Astuti ${ }^{2}$ \\ ${ }^{1}$ Medical Surgical Nursing, STIKES RS. Baptis Kediri \\ ${ }^{2}$ Basic Nursing, STIKES RS. Baptis Kediri \\ Email: erva.kristini@gmail.com
}

Received 13 September 2018; Accepted 1 February 2019; Published 22 May 2019

\begin{abstract}
Pre-diabetes is the beginning of diabetes. Pre-diabetes is not yet included in diabetes but can become Diabetes Mellitus. Pre-diabetes is characterized by fasting blood sugar levels of 100-125 $\mathrm{mg} / \mathrm{dl}$ and blood sugar 2 hours after eating 140-199 mg/dl. The pre-diabetes condition can naturally develop diabetes but can be prevented. Therefore, it is very important to know the attitude in preventing pre-diabetes and its complications so that behaviors that lead to healthy life can be achieved. The objective of this study was to determine the characteristics of pre-diabetes and describe the attitude of pre-diabetes prevention and its complications in Bangsal District of Kediri. The design used in this study was descriptive. The study population was all who were at risk of pre-diabetes in Bangsal District of Kediri. The samples were 30 respondents taken with quota sampling technique according to the inclusion criteria. The research variable was description of the attitude of prediabetes prevention in Bangsal District of Kediri. Data analysis was presented in the frequency distribution table. The results showed that the attitude of pre-diabetes prevention and its complications were mostly sufficient as many as 18 respondents (60\%) and less than half were good as many as 12 respondents $(40 \%)$. Based on the results it can be concluded that the attitude of prevention of prediabetes and its complications in Bangsal District of Kediri was sufficient so that there was necessary to increase attitudes that lead to increase in health status.
\end{abstract}

Keywords: Attitude, pre-diabetes prevention

Copyright () 2019 STIKes Surya Mitra Husada

All right reserved.

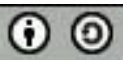

This is an open-acces article distributed under the terms of the Creative Commons AttributionShareAlike 4.0 International License.

\section{INTRODUCTION}

Diabetes Mellitus (DM) is a chronic disease and is characterized by an increase in blood sugar levels exceeding normal followed by disorders of metabolism of carbohydrates, fats and proteins because the body's insulin deficiency, both relative and absolute (Darmono, 2007 in Hasdianah, 2012). The most diabetes mellitus in Indonesia is DM type 2 with almost more than 90\% of all populations (Diabetes Center and Lipid Faculty of Medicine, University of Indonesia, 2005). DM type 2 can actually be prevented, especially with improvements in lifestyle, activity, diet and treatment. Diabetes begins with metabolic syndrome caused by a disturbance of insulin secretion by the pancreas. Blood sugar levels rise above normal or often referred to as pre-diabetes. Pre-diabetes has not yet been categorized as diabetes but carries complications in the incidence of DM (Soewondo $\&$ Pramono, 2011). According to the American Diabetes Association (2016) states that pre-diabetes is characterized by fasting blood sugar levels of $100-125 \mathrm{mg} / \mathrm{dl}$ and blood sugar 2 hours after eating 140-199 mg/dl. The pre-diabetes condition can naturally develop diabetes but can be prevented (Twigg, et al, 2007). According to the International Diabetes Federation (2000) in the Center for 
Diabetes and Lipid (2007) Indonesia's population above the age of 20 by 125 million suffering from diabetes is estimated to enter diabetes conditions around 4.6\%. This assumption is expected to continue to increase until 2020 to 8.3 million patients. While according to Eliza \& Sofitri (2012) the prevalence of pre-diabetes in Indonesia is estimated at around 300 million Indonesian population has entered pre-diabetes (Elliza \& Sofitri, 2012).

Pre-diabetes can be experienced by anyone with several risk factors including age more than equal to 25 years with an increase in fasting blood sugar by 1-2 $\mathrm{mg}$ per year and blood sugar two hours after eating 5.6-13 mg per year (Twigg, et al ., 2007 and WHO in Wulandari, 2014). The condition of pre-diabetes can increase the risk of atherosclerosis caused by endothelial damage to blood vessels due to increased blood sugar and can increase the risk of diabetes mellitus, heart disease and other macro-vascular diseases (Ciccone, et al, 2014), pre-diabetes also causes hyperinsulinemia which plays a role in increasing re-absorption of uric acid in the proximal renal tubule resulting in hyperuricemia which leads to the condition of Diabetes so prevention efforts must be carried out by checking blood sugar for a maximum of 1 month (Ellyza \& Sofitri, 2009). Pre-diabetes does not cause typical symptoms and most are asymptomatic therefore it is important to know its prevention (Evans, P.H., Winder, R., Greaves C.J., \& Campbell, 2007). Efforts to improve health behavior through health promotion activities by providing health education are one solution to prevent pre-diabetes (Sovia, Etty Rekawati \& Kuntarti, 2013). Through health education it is expected that knowledge will increase where knowledge is one component in the formation of attitudes.

Attitude is a mental and nervous state of readiness, organized through experience, exerting direct influence on individual responses to all objects and related situations (Stonea et al, 2005 in Abolghasemi \& Sedaghat, 2015). Attitude is not yet an action or activity, but it is a predisposition of action or behavior (Soekidjo Notoatmojo, 2011). The attitude component consists of cognitive components, affective components and cognitive components (Wawan \& Dewi, M, 2010 and Evans et al, 2007). Meanwhile, according to Mubarak Iqbal, et al (2007) states that attitude consists of three components, namely the attitude component consists of beliefs or beliefs, ideas and concepts of an object, emotional life or emotional evaluation of an object, and the tendency to act (trend to behave). These three components together can form a total attitude. Whereas the attitude if associated with education can mean a response to the educational material provided. Attitudes are influenced by many factors including personal experience, the influence of others who are considered important, cultural influences, mass media, educational institutions and religious institutions and emotional factors (Mubarak Iqbal, et. Al, 2007).

\section{MATERIALS AND METHODS}

The design of this study was descriptive to describe the attitude of pre-diabetes prevention and its complications in Bangsal District of Kediri. This research was conducted on 23 April - 23 May 2018 in Bangsal District of Kediri which consisted of 7 RWs with the taking of respondents according to the inclusion criteria through quoata sampling technique and the number of respondents in RW 1, 5 respondents, RW 2 were 5 respondents, RW 3 as many as 5 respondents, RW 4 as many as 5 respondents, RW 5 as many as 5 respondents, RW 6 as many as 5 respondents and RW 7 as many as 5 respondents. Total respondents in the study were 30 who met the inclusion criteria. The research variable was the attitude of pre-diabetes prevention in Bangsal District of Kediri. Data collection is done by giving a questionnaire with a total of 25 questions. The collected data is carried out descriptive analysis test using frequency distribution test.

\section{RESULTS}

\section{Characteristics of Pre-diabetes in Bangsal District of Kediri}

Based on the results of the study, it was found that respondents in the Bangsal District consisting of $7 \mathrm{RWs}$ had an average age of respondents was 55 years with the youngest age of 34 years and the oldest age was 75 years. The average body weight of respondents was $63.9 \mathrm{~kg}$ with the lowest weight $49 \mathrm{~kg}$ and the highest is $97 \mathrm{~kg}$. The waist circumference of the respondent was on average $94.6 \mathrm{~cm}$ with the smallest waist circumference of $67 \mathrm{~cm}$ and the largest waist circumference 
was 116. Respondents had an average height of $155.9 \mathrm{~cm}$ with a minimum height of $145 \mathrm{~cm}$ and a maximum height of $168 \mathrm{~cm}$.

2. The attitude of pre-diabetes prevention and its complications in Bangsal District of Kediri

Table 1 Attitude of Pre-diabetes Prevention and its Complications in Bangsal District of Kediri

\begin{tabular}{llcc}
\hline \multirow{2}{*}{ Variables } & \multicolumn{2}{c}{$\begin{array}{c}\text { Attitude Of Prediabetes Prevenstion and Its Complications in Bangsal } \\
\text { District of Kediri }(\mathrm{n}=30)\end{array}$} \\
\cline { 3 - 4 } & $\mathrm{f}$ & $\%$ \\
\hline- & Very good & 0 & 0 \\
- & Good & 12 & 40,0 \\
- & Sufficient & 18 & 60,0 \\
- & Poor & 0 & 0 \\
\hline
\end{tabular}

Based on the table above it can be seen that the attitude of pre-diabetes prevention and its complications was sufficient was as many as 18 respondents $(60 \%)$ and less than half with good prevention attitude of 12 respondents $(40 \%)$.

\section{DISCUSSION}

\section{Characteristics of Pre-diabetes in Bangsal District of Kediri}

Characteristics of respondents in Bangsal District of Kediri based on the average study age of respondents was 55 years with the lowest age of 34 years and the highest age was 75 years. Based on the results of the study, the majority of respondents had entered Pre-diabetes as many as 19 respondents $(63.3 \%)$. As age increasing, the function of the pancreas decreased physiologically. Decreased pancreatic function could result in less sensitive pancreas to react when insulin in the blood drops. Physiologically the pancreas would provide positive feedback by increasing insulin production when insulin in the blood drops. However, in the pre-diabetes the pancreas did not react so that insulin was not produced sufficiently to normalize blood sugar levels (Smeltzer \& Bare, 2001). This was also evidenced by the results of the pre-diabetes survey respondents mostly entering prediabetes as many as 19 respondents $(83.3 \%)$. Researcher assumed that age could affect insulin production because the pancreas had decreased physiologically in insulin secretion. According to WHO in Wulandari (2014) states that every increase in age of more than 25 years will naturally increase blood glucose around 1-2 mg/dl per year and blood glucose after meals around 5.6-13 mg/dl per year. According to the analysis of researcher, the increase in age affects the function of the pancreas in producing insulin so that insulin was not sufficiently produced. Normally insulin acts to maintain blood sugar levels. But if the quantity of insulin decreased in number, blood sugar continues to circulate throughout so that blood sugar levels could not be distributed by the body to organs that needed it, such as the muscles. This happened because the amount of insulin as a mediator of blood sugar channels to the muscles decreased in number. The result of a lack of insulin was an increase in blood sugar levels. This mechanism was also referred to as insulin resistance which meant that insulin sensitivity to blood sugar decreased.

Disease Control and Prevention National Diabetes Statistics Report (2014) and Heikes (2008) are associated with increasing age by increasing blood sugar levels. Pre-diabetes occurs over the age of 20 years and in the age range of less than 44 years to more than 57 years there will be an increase in blood sugar levels both fasting blood sugar and after eating. An increase in blood sugar levels above normal causes a person to fall in pre-diabetes.

Respondents in Bangsal District of Kediri also had an average waist circumference of 95.6 with a minimum body weight of $49 \mathrm{~kg}$ and a maximum body weight of 97 and an average height of $156.9 \mathrm{~cm}$. According to the results of research conducted by Darmayanti, D (2014) states that anthropometry consisting of weight; height is a measurement technique that can be done to detect central obesity. Central obesity is related to blood sugar control disorders and results in insulin resistance. Researchers assume that respondents with obesity conditions have a high risk of entering 
pre-diabetes. This opinion is supported by the results of research conducted by Pramono (2011) and Andan, Mulyati, Isworo (2013) which state that there is a positive correlation between the middle level between anthropometry and obesity and central obesity. This is also evidenced by the calculation of the average BMI of respondents in the average body weight and height of respondents had entered the BMI criteria for excess body weight with a score of 25 .

The results also showed that respondents had an average waist circumference of $94.6 \mathrm{~cm}$. According to the results of research conducted by Tandra (2009) waist circumference is one indicator of metabolic syndrome in patients with diabetes mellitus. Metabolic syndrome occurs because insulin receptors cannot capture blood sugar and are then stored in the muscle. The impact that occurs when insulin is not sensitive to blood sugar is an increase in blood sugar levels. According to the assumption of the researcher, the difference in waist circumference variance is caused by the prediabetes condition; blood sugar levels experience an increase above normal but do not lead to a diagnosis of diabetes. Pre-diabetes can occur where one of the risk factors is waist circumference. So, the waist circumference could not be used as a reference to assess the condition of pre-diabetes. This opinion was confirmed by Heikes (2008) which states that waist circumference is one of the criteria for factors that influence a person to enter pre-diabetes with a waist circumference of more than 98 $\mathrm{cm}$. The results showed an average waist circumference of $94.6 \mathrm{~cm}$ is a risk factor that can lead to pre-diabetes if the respondent does not have a good attitude in preventing an increase in waist circumference because it is above the normal value of the average waist circumference of a woman. According to Hartono (2005) and Utaminingsih (2009) in Manungkalit, Kusnanto \& Purbosari (2015) waist circumference is one way to measure the distribution of fat in the body. Normal size of waist circumference in Asians (women $80 \mathrm{~cm}$ and men $90 \mathrm{~cm}$ ) if it exceeds the normal value then the risk of developing coronary heart disease due to changes in metabolism, including sensitivity to insulin and increase the production of bad fats in the body and is the main factor triggering the onset of degenerative diseases Diabetes mellitus. According to the assumption of researchers the waist circumference above normal can cause metabolic disorders that can increase blood sugar a level increase above normal as in pre-diabetes but does not directly cause blood sugar levels to rise significantly as in diabetes.

The results also showed that the most respondents' blood pressure was normal to prehypertension. In theory, blood pressure can affect the increase in blood sugar. Because blood pressure can trigger the onset of metabolic syndrome which results increases in blood sugar. In addition, the result of the study showed that the majority of respondents did not work Pre-diabetes was closely related to lack of physical activity. According to Pramono (2011) physical activity, lacking intermediate to strong correlation with pre-diabetes conditions. The results of other studies conducted by Retno, D (2012) also state that there is a positive relationship between pre-diabetes and physical activity. This is evidenced from the results of the study that the majority of respondents did not work so the researchers assumed that lack of physical activity could affect the lack of movement and this could lead to the occurrence of pre-diabetes.

According to the assumption of researchers physical activity is very useful for the use of blood sugar. During physical activity the muscle will contract to cause movement. Contraction of the muscle is the result of the breakdown of sugar stored in the muscle which is then converted into energy. Energy is then needed by the muscles to produce movement. The use of stored sugar will then affect the decrease in blood sugar levels because the use of sugar in the muscles does not require insulin as the mediator. This is also in line with research conducted by Puji, Heru \& Agus, S (2007) which states that physical activity can trigger regulation and control of blood sugar levels, because when doing physical activity there will be the use of glucose in the muscles that do not require insulin as a mediator use of glucose into muscle cells so that blood sugar levels decrease. Conversely the lack of physical activity carried out by respondents can have an impact on the increase in blood sugar above normal because blood sugar will be circulated back to the blood so that an increase in blood sugar levels. This is consistent with the pre-diabetes criteria proposed by Heikes (2008) that the risk of pre-diabetes conditions is also influenced by physical activity. So researchers assume that lack of physical activity can increase blood sugar levels and lead to pre-diabetes.

The results of the study showed that the parents or siblings had the most major history but did not have DM children but were included in the pre-diabetes condition. According to the Pre-diabetes Consensus Statement (2008) a history of parents or siblings with Diabetes Mellitus is a factor that could not be changed but not all diabetes changes to DM type 2. Diabetes which occurs due to 
abnormalities in the pancreas will be genetically inherited. The risk of pre-diabetes increases more in the offspring of parents or siblings with Diabetes Mellitus as well as a history of diabetes in pregnancy. Pre-diabetes apart from genetic factors is also caused by non-genetic factors such as diet, lack of physical creativity and this can affect the incidence of pre-diabetes even though the family does not have a history of hereditary DM.

The results showed that respondents in the Kediri City Ward had normal blood pressure to pre-hypertension. According to Garber et al (2008) maintaining blood pressure of less than 130-80 $\mathrm{mmHg}$ can minimize the progress of pre-diabetes. Respondents in pre-diabetes have normal blood pressure to pre-hypertension. Researchers assume that blood pressure rises from normal can affect the body's metabolism, which results in an increase in blood sugar levels. This opinion is confirmed by the results of a study conducted by Pramono (2011) that the incidence of pre-diabetes can be affected by blood pressure. Increased blood pressure can inhibit the pancreas in producing insulin so that blood sugar levels increase from normal.

In addition, respondents in the pre-diabetes condition in the ward of the Kediri city ward were the most with the lowest level of education at the level of junior high school education. Education is a means to provide information guided to achieve a goal. Through education information messages can be delivered. In general, the lower the education and understanding of health. This is in line with the results of research conducted by Fajrinayanti \& Ayubi D (2008) which states that pre-diabetes behavioral factors are influenced by family knowledge, family type, family income and family health care practices.

Based on this, the researchers assumed that the pre-diabetes condition had not been categorized as diabetes mellitus where chronic insulin resistance had occurred; respondents with BMI above normal could affect the use of glucose in the muscles and increase the risk of complications from pre-diabetes. During the pre-diabetes condition, you can do the activity or exercise, the sugar level will be used by the body as energy so that blood sugar decreases. However, in the condition of a high category of body mass index is not balanced with activity, there will be a significant increase in blood sugar levels. It is also associated with high lipid conditions when overweight can also interfere with insulin sensitivity

\section{Attitudes of Pre-diabetes Prevention and its complications in Bangsal District of Kediri.}

The pre-diabetes prevention attitude and its complications were considered sufficient by respondents with a male gender of $75 \%$, while the attitude assessment was given quite a lot by respondents with a junior high school level (73.3\%), while the assessment was sufficient also given a lot of respondents with the most work history is private. Attitude changes relate to the lack of a supporting factor for the emergence of motivation in achieving goals (Yusnita, 2001). Attitude is a response or reaction that is still closed from a stimulus or object (Syafrudin and Yudiha, 2009). A person's attitude is influenced by trust, emotional life, and the tendency to act. Attitudes can be formed after a new stimulus. Stimulus can be information obtained directly or through the media. Information can be easily accepted if it attracts readers' interests as well as the media presented. Before giving the book, the information received by the respondents was very limited so that the attitude was not well formed.

\section{CONCLUSION}

The results showed that the attitude of pre-diabetes prevention its complication was sufficient. This would certainly affect the prevention behavior of pre-diabetes because attitude was a component of closed behavior. So that it was hoped that efforts would be made to improve positive attitudes towards pre-diabetes prevention and its complications in the Bangsal District of Kediri. 


\section{REFERENCE}

Abolghasemi, \& Sedaghat. (2015). The Patient's Attitude Toward Type 2 Diabetes Mellitus, a Qualitative study. Relig Health 54:1191-1205 DOI 10.1007/s10943-014-9848-9 J. Diakses tgl 11 Nopember 2018. https://link.springer.com/content/pdf/10.1007\%2Fs10943-014-9848-9.pdf.

American Diabetes Association. (2016). Prediabetes. Diakses di http://www.diabetes.org/are-you-atrisk/prediabetes/belajar tentang prediabeteshttp://www.diabetes.org/newsroom/press-releases/2016/first-of-itskind-psa-campaign-targets-86-million-american-adults-with-prediabets.html?loc=news_ad-council english _jan2016?referrer=http://www.diabetes.org/?loc=logo.

Bare, B., G., \& Smeltzer, S., C. (2001). Buku Ajar Keperawatan Medika l Bedah. Jakarta: EGC.

Ciccone, M., M., Scicchitano, P., \& Camel, M., et al. (2014). Endotelial Function in Pre diabates, Diabetic and Diabetic Cardiomyopathy: A Review. Journal Diabetes Metabolism. ISSN: 2155-6156 JDM, an open access journal Volume $5 \cdot$ Issue $4 \cdot 1000364$

Ellyza, Nasrul, \& Sofitri. (2012). Hiperurisemia Pada Pradiabetes. Diakses dalam jurnal Andalas ISSN: 23017406 vol 1 no 2 di akses di http:// jurnal.fk.unand.ac.id tgl 15 Januari 2016.

Evans, P., H., Winder, R., Graves, C., J., \& Campbell, J., L. (2007). Development of an Educational 'Toolkit' for health professional and their patient with prediabates: The WAKEUP study (Ways of Addresing Knowledge Education and Understanding in Prediabates). Journal compilation (C) 2007 Diabetes UK.Diabetic Medicine. DOI: $\quad 10.1111 / \mathrm{j} .1464-5491.2007 .02130$. diakses pada tgl 27 Januari $2016 \quad$ di https://www.researchgate.net/publication/51384732.

Hasdianah. (2012). Mengenal Diabetes Melitus. Jilid 1. Nuha Medika: Kediri.

Mubarak, \& Iqbal, et al. (2009). Ilmu Keperawatan Komunitas Pengantar dan Teori. Jakarta: Salemba Medika.

Notoatmodjo, S. (2011). Kesehatan Masyarakat Ilmu dan Seni. Rineka Cipta; Bandung.

Pusat Diabetes dan Lipid Fakultas Kedokteran Universitas Indonesia. (2007). Penatalaksanaan Diabetes Melitus Terpadu; FKUI, Jakarta.

Soewondo, \& Pramono, L., A. (2011). Prevalence, Characteristics, and Predictor of Prediabetes in Indonesia. Medical Journal Indonesia Vol 20 No 4 November 2011.

Sovia, Etty, \& Kuntarti. (2013). Hubungan Karakteristik Keluarga dan perilaku Perawatan Kesehatan keluarga dengan Kejadian Prediabetes Pada Usia Dewasa Menengah di Kelurahan Cisalah Pasar Kecamatan Cimanggis Kota Depok. Tesis. Fakultas Ilmu Keperawatan Program Magister Keperawatan Komunitas. Depok.

Twigg, S., M., Davis, T., \& Kamp, M. (2007). Australian Diabetes Society; Australian Diabetes Educators Association. Prediabetes: a position statement from the Australian Diabetes Society and Australian Diabetes Educators Association. The Medical Journal Of Australia, Volume 186. Number 9, Capther 460-465. diakses tgl 27 Januari 2016 di https://www.researchgate.net/publication/6346117.

Wawan, A., \& Dewi, M. (2010). Teori dan Pengukuran Pengetahuan, Sikap dan Perilaku Manusia. Nuha Medika, Jakarta.

Wulandari. (2014). Pengaruh Pemberian Brokoli Kukus (Bassica Oleracea) Terhadap Kadar Glukosa Darah Puasa Wanita Prediabetes. Skripsi Program Gizi Fakultas Universitas Sumatera Utara. Diakses tgl 19 Juli 2016 dihttp://eprints.undip.ac.id/45193/1/646_Nirmaya_Esthi_Wulandari.pdf. 